\title{
Geomedia
}

Majalah Ilmiah dan Informasi Kegeografian

Geomedia Vol. 19 No. 1 Tahun 2021 | 35 - 45

https://journal.uny.ac.id/index.php/geomedia/index

\section{Deteksi permukiman kumuh menggunakan informasi spektral dan tekstur citra penginderaan jauh (studi di sebagian kota Yogyakarta)}

\author{
Achmad Fadhilah ${ }^{a, 1^{*}}$, Prima Widayani ${ }^{b, 2}$, Iswari Nur Hidayati ${ }^{c, 3}$ \\ a Program Studi S2 Penginderaan Jauh Fakultas Geografi Universitas Gadjah Mada, Yogyakarta, Indonesia \\ b,c Departemen Sains Informasi Geospasial Fakultas Geografi Universitas Gadjah Mada, Yogyakarta, Indonesia \\ 1 achmadfadhilah@mail.ugm.ac.id*; primawidayani@ugm.ac.id; iswarinh@ugm.ac.id \\ *korespondensi penulis
}

\begin{tabular}{ll}
\hline \multicolumn{2}{l}{ Informasi artikel } \\
\hline Sejarah artikel \\
Diterima & $: 17$ April 2021 \\
Revisi & $: 1$ Mei 2021 \\
Dipublikasikan & $: 31$ Mei 2021 \\
\hline
\end{tabular}

\section{Kata kunci:}

Permukiman Kumuh

Spektral

Tesktur

Multiresolusi Spasial

\begin{abstract}
A B S T R A K
Pemetaan dan identifikasi merupakan tahap awal dalam program peningkatan kualitas permukiman kumuh. Pemetaan permukiman kumuh saat ini masih menggunakan metode survei langsung yang membutuhkan banyak biaya, waktu, dan tenaga. Penelitian ini bertujuan untuk mendeteksi keberadaan permukiman kumuh menggunakan citra penginderaan jauh sebagai metode alternatif dalam mengidentifikasi permukiman kumuh. Citra yang digunakan dalam penelitian ini antara lain: Pleiades-1B, SPOT-7, dan Sentinel-2. Studi ini berlokasi di sebagian Kota Yogyakarta yang dibagi dua daerah penelitian. Algortima Support Vector Machine (SVM) digunakan untuk mengkelaskan permukiman kumuh dan bukan kumuh. Parameter yang digunakan dalam penelitian ini antara lain: Saluran multispektral, Grey Level Co-occurrence Matrx (GLCM), dan Normalized Difference Vegetation Index (NDVI). Validasi dilakukan dengan menggabungkan data sekunder peta permukiman kumuh dan hasil observasi lapangan. Hasil penelitian menunjukkan bahwa tingkat akurasi klasifikasi tertinggi dihasilkan dari layer Sentinel-2 GLCM 3×3 sebesar $56,26 \%$ pada daerah penelitian 1 , sedangkan pada daerah penelitian 2 diperoleh dari layer Pleiades-1B GLCM 9x9 sebesar 66,17\%.
\end{abstract}

Keywords:
Slum Area
Spectral
Texture
Spatial Multiresolusion

\begin{abstract}
A B S T R A C T
Mapping and identifying were early stages on slum upgrading program. Slum mapping is recently still conducted by survey-based mapping that require more cost, time, and surveyor. This study aims to detect slum areas using remote sensing satellite imagery as an alternative method of identifying slum areas. The satellite imageries that used in this study were Pleiades-1B, SPOT-7, and Sentinel-2. This research was located in some parts of Yogyakarta City that divided into two areas. The Support Vector Machine (SVM) algorithm was used to classify slum and non-slum areas. The parameter used in this this study include: Multispectral bands, Gray Level Co-occurrence Matrix (GLCM, and Normalized Difference Vegetation Index (NDVI). Yogyakarta City slum map and field validation were conducted to test the accuracy of the image classification results. The results showed that the highest classification level is $56,26 \%$ in study area 1 while in study area 2 reaches $66,17 \%$ respectively generated by Sentinel2 GLCM 33 and Pleiades-1B GLCM 3x3 layers.
\end{abstract}




\section{Pendahuluan}

Permukiman kumuh merupakan permukiman yang tidak layak huni karena ketidakteraturan bangunan, tingkat kepadatan bangunan yang tinggi, dan kualitas bangunan serta sarana prasarana yang tidak memenuhi syarat (UU No. 1 tahun 2011). Kawasan permukiman kumuh biasanya berasosiasi dengan kawasan industri, sekitar badan air, dan sepanjang jalan rel kereta api (Muta'ali dan Nugroho, 2016). Dilihat dari karakteristik umumnya, permukiman kumuh dapat dilihat dari beragam aspek meliputi: lokasi, kepadatan dan keteraturan bangunan, akses jalan, bentuk dan kualitas bangunan (Kohli et al, 2012). Keberadaan permukiman kumuh di perkotaan menimbulkan berbagai masalah terutama berkaitan dengan kondisi lingkungan yang buruk. Diperlukan upaya penanganan oleh berbagai pihak baik dari pemerintah, lembaga non-pemerintah, dan masyarakat di kawasan permukiman kumuh.

Salah satu wilayah perkotaan yang memiliki kawasan permukiman kumuh adalah Kota Yogyakarta. Permukiman kumuh di Kota Yogakarta sebagian tersebar di bantaran Sungai Code dan Winongo. Pemerintah setempat telah menerbitkan peta permukiman kumuh pada tahun 2016. Pemetaan permukiman kumuh di Kota Yogyakarta menggunakan metode survei langsung ke lapangan sehingga membutuhkan banyak waktu dan tenaga. Diperlukan bantuan metode tertentu untuk menentukan dan memetakan lokasi permukiman kumuh secara efektif dan efisien.

Salah satu metode alternatif pemetaan permukiman kumuh adalah pemetaan dengan bantuan penginderaan jauh. Teknologi penginderaan jauh menghasilkan luaran berupa citra dengan berbagai resolusi spasial dari resolusi rendah hingga sangat tinggi. Pemetaan permukiman khususnya daerah perkotaan umumnya menggunakan citra resolusi spasial sangat tinggi (CRST). Hal ini dikarenakan keunggulan CRST mampu mendeteksi secara detail objek rumah. Di sisi lain, CRST juga memiliki kelemahan dalam hal penyimpanan data yang besar dan pemrosesan yang lama.

Citra penginderaan jauh mengandung informasi berupa nilai spektral yang besarnya tergantung dari respon panjang gelombang elektromagentik dari objek di permukaan bumi. Setiap panjang gelombang memiliki nilai kekuatan tertentu pada jenis objek yang berbeda (Richards dan Jia, 2005). Permukaan bumi yang didominasi oleh lautan, vegetasi, tanah, dan air permukaan, masing-masing dapat dibedakan berdasarkan karakter spektral (respon panjang gelombang elektormagnetik) (Baghdadi dan Zribi, 2016). Pada beberapa jenis objek, perbedaan nilai spektral tidak kentara sehingga sulit dibedakan, Dalam studi permukiman kumuh, hal tersebut menyulitkan saat melakukan klasifikasi antara permukiman kumuh dan bukan kumuh. Diantara informasi citra yang berfungsi membedakan objek yang relatif sama adalah tekstur. Tekstur merupakan informasi spasial penting yang dapat membedakan beberapa objek yang memiliki kesamaan ciri spektral (Kupidura, 2019).

$$
\text { Beberapa studi terdahulu telah }
$$
menggunakan informasi tekstur dan spektral citra untuk mendeteksi permukiman kumuh. Penelitian Mboga et. al. (2017) menggunakan informasi tekstur GLCM citra Quickbird untuk identifikasi permukiman informal. Penelitian yang dilakukan sebelumnya oleh Kuffer et. al. (2016b) hanya menggunakan fitur tesktur variance GLCM dan NDVI dari citra WorldView-2 untuk klasifikasi permukiman kumuh. Parameter-parameter terpilih baik gabungan dari infomasi spektral dan tekstur maupun hanya dari informasi tekstur saja pada penelitian-penelitian di atas diklasifikasi dengan algorima machine learning. Metode machine learning telah digunakan untuk pemetaan permukiman kumuh sebanyak 11 penelitian dalam rentang waktu tahun 2000 hingga 2015 (Kuffer et. al., 2016). Parameterparameter yang digunakan dalam beberapa penelitian yang menggunakan metode machine learning bersifat eksploratif untuk mendapatkan informasi repetitif dengan jumlah fitur 
parameter/dataset yang banyak. Jumlah fitur parameter yang banyak menyebabkan proses komputasi berlangsung lama dan membutuhkan spesifikasi komputer yang memadai.

Penelitian ini menggunakan beberapa citra penginderaan jauh, meliputi: Pleiades-1B, SPOT-7, dan Sentinel-2 sebagai representasi citra resolusi spasial sangat tinggi, tinggi, dan menengah untuk deteksi permukiman kumuh. Penelitian ini menggunakan variabel informasi spektral dan tekstur yang dapat diekstrak langsung dari citra. Saluran multispektral digunakan untuk membedakan objek permukiman dan nonpermukiman berdasarkan dari karakteristik spektral. Indeks Normalized Difference Vegetation Index (NDVI) untuk mendeteksi keberadaan vegetasi. Nilai NDVI rendah mengindikasikan jarang terdapat vegetasi yang menjadi salah satu ciri permukiman kumuh. Selanjutnya, informasi tekstur dari Grey Level Co-occurrence Matrix (GLCM) digunakan untuk mendeteksi tekstur dengan cara operasi piksel ketetanggaan (Neigborhood Operation). Mayoritas bangunan di area permukiman kumuh berukuran kecil sehingga pada ukuran window GLCM tertentu tekstur nampak halus dan memiliki variasi yang rendah. Kemudian, semua layer variabel digabung untuk diklasifikasi menggunakan klasifikasi Support Vector Machine. Selanjutnya dilakukan cek lapangan untuk mendapatkan data lokasi permukiman kumuh. Uji akurasi dilakukan dengan cara membandingkan hasil klasifikasi dengan data lapangan dan peta lokasi permukiman kumuh Kota Yogyakarta.

\section{Metode}

Penelitian ini berlokasi di sebagian wilayah Kota Yogyakarta. Daerah penelitian terdiri atas daerah penelitian 1 dan daerah penelitian 2 . Daerah penelitian 1 secara administrasi berada di Kelurahan Karangwaru, Cokrodiningratan, Terban, Kotabaru, dan Gowongan, sedangkan daerah penelitian 2 berada di Kelurahan Giwangan, Pandeyan, dan Sorosutan. Secara geografis, daerah penelitian 1 dilalui oleh Sungai Code dan Sungai Buntung. Adapun daerah penelitian 2 diapit oleh Sungai Code dan Sungai Gajahwong. Lokasi penelitian ditunjukkan oleh Gambar 1 berikut ini.

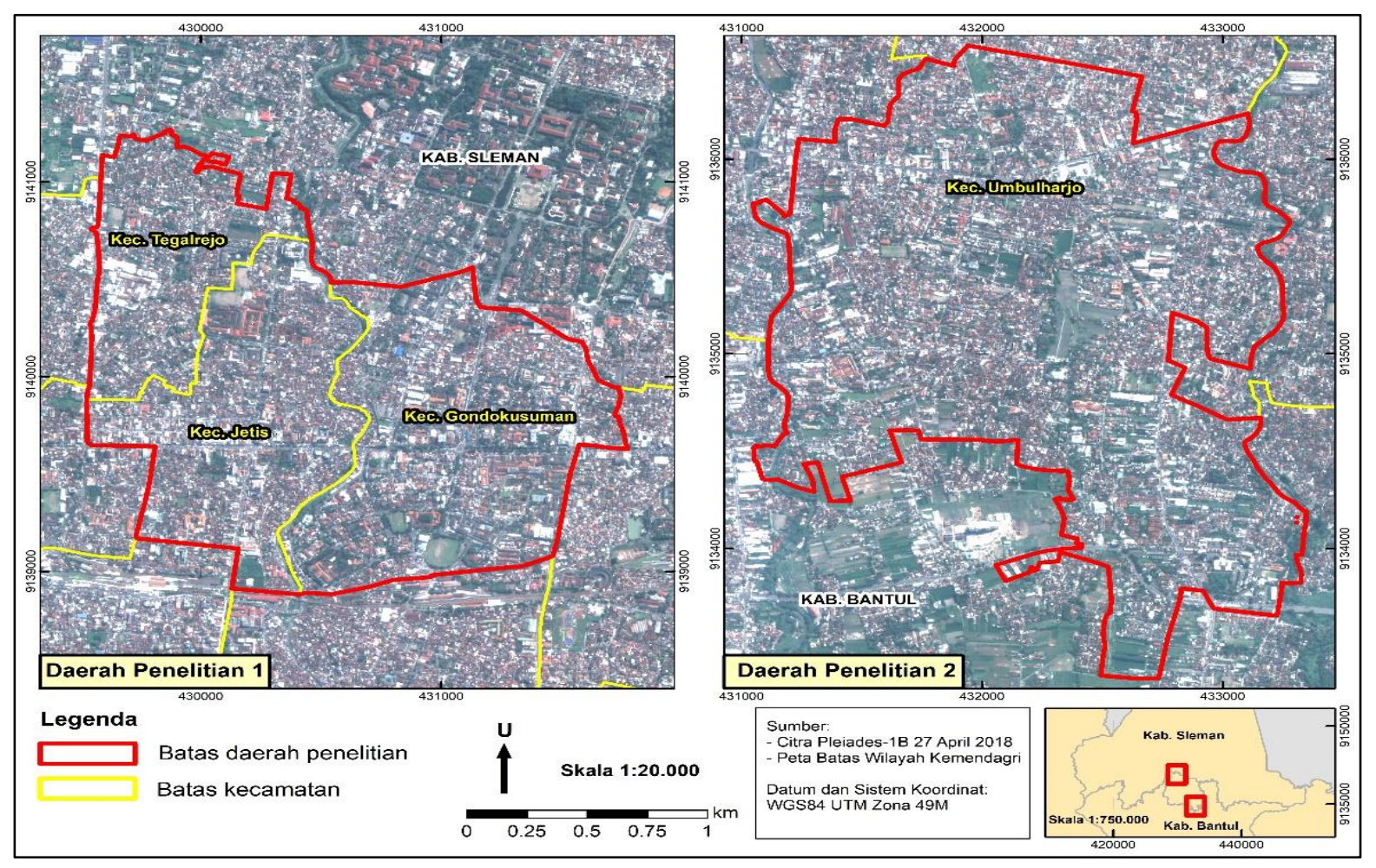

Gambar 1. Peta Daerah Penelitian 
Perbedaan karakteristik permukiman kumuh dari kedua lokasi tersebut adalah pada asosiasi dan pola persebarannya. Permukiman kumuh di daerah penelitian 1 berada di sempadan sungai sedangkan permukiman kumuh daerah 2 tersebar secara merata.

Informasi parameter yang digunakan dalam penelitian ini diperoleh dari data penginderaan jauh untuk mewakili kenapakan nyata di lapangan. Informasi spektral dari saluran multispektral citra digunakan untuk menampilkan perbedaan objek berdasarkan warna dan karakteristik spektralnya pada tiap objek. Dalam klasifikasi digital, perbedaan nilai spektral merupakan komponen dan syarat utama untuk mengklasifikasi beberapa objek. Misal objek vegetasi memiliki nilai pantulan spektral yang tinggi pada saluran hijau dan inframerah dekat, sebaliknya atap rumah memiliki pantulan spektral yang rendah pada kedua saluran tersebut dan pantulan tinggi pada saluran merah. Hal inilah yang menjadi dasar dalam klasifikasi objek pada citra penginderaan jauh.

\section{Normalized Difference Vegetation Index (NDVI)}

Indeks NDVI merupakan indeks yang menonjolkan informasi spektral dari inframerah dekat yang sensitif terhadap vegetasi. Indeks NDVI saat ini merupakan indeks vegetasi yang paling populer dan banyak digunakan untuk penilaian vegetasi (Huang et al, 2021, Somvanshi dan Kumari, 2020, Xue dan Su, 2020). Kelebihan indeks NDVI adalah rumus relatif sederhana dan lebih mudah mendelineasi vegetasi namun mudah terganggu oleh efek atmosfer dan saturasi uap air pada tanaman (Huang et al, 2021, Xue dan Su, 2020). Pada umumnya, area bervegetasi dan ruang terbuka hijau jarang tersedia di kawasan permukiman kumuh yang padat (Sori, 2012). Hal tersebut dikarenakan jumlah penduduk dan kebutuhan hunian yang tinggi sehingga lahan banyak digunakan untuk bangunan tempat tinggal. Pada area lahan terbangun dan permukiman, nilai NDVI lebih rendah daripada area bervegetasi. Hal ini disebabkan oleh pantulan
NIR pada area lahan terbangun lebih rendah sedangkan pantulan NIR pada area bervegetasi lebih tinggi. Sebaliknya, pantulan saluran merah lebih tinggi di lokasi permukiman daripada area bervegetasi. Perhitungan nilai NDVI mengunakan rumus sebagai berikut:

$$
N D V I=\frac{N I R-R}{N I R+R}
$$

dimana, NIR = saluran inframerah dekat, $\mathrm{R}=$ saluran merah. Prinsip NDVI adalah menonjolkan nilai NIR dengan cara mengurangi dan membaginya dengan saluran merah sehingga nilai indeks yang dihasilkan lebih menguatkan nilai NIR. Nilai/indeks NDVI berkisar antara - 1 hingga 1, dimana nilai mendekati 1 semakin menunjukkan keberadaan vegetasi. Area tanah berbatu dan pasir umumnya menunjukkan nilai NDVI yang rendah (dibawah 0,1). Semak belukar dan rerumputan biasanya memiliki nlai NDVI sedang antara 0,2 hingga 0,5 . Nilai NDVI tinggi antara 0,6 hingga 0,9 biasanya menjukkan vegetasi dengan kerapatan kanopi yang tinggi (Brown, 2018).

Nilai NDVI sering dikaitkan dengan persentase kerapatan vegetasi. Namun demikian, persentase tersebut masih perlu dianalisis dengan analisis korelasi antara nilai NDVI pada citra dengan hasil pengukuran lapangan. Dalam penentuan area bervegetasi dengan NDVI, perlu dilakukan pembatasan nilai ambang (threshold) nilai NDVI untuk menentukan rentang nilai NDVI dapat dikatakan bervegetasi atau tidak. Hal ini juga berlaku untuk membedakan antara area bervegetasi dengan lahan terbangun, terutama permukiman, dan objek lain non-vegetasi. Penelitian ini tidak menggunakan threshold dikarenakan penggunaan tiga jenis citra yang berbeda. Perbedaan jenis citra, resolusi spasial, dan rentang spektrum membutuhkan jenis rentang nilai NDVI yang berbeda juga untuk membedakan area bervegetasi. Nilai NDVI digunakan sebagai parameter yang dipilih menggunakan beberapa titik sampel pada lokasi penelitian yang juga mengambil fitur parameter lainnya untuk mendeteksi permukiman kumuh. 
Perhatikan Gambar 2 berikut ini.

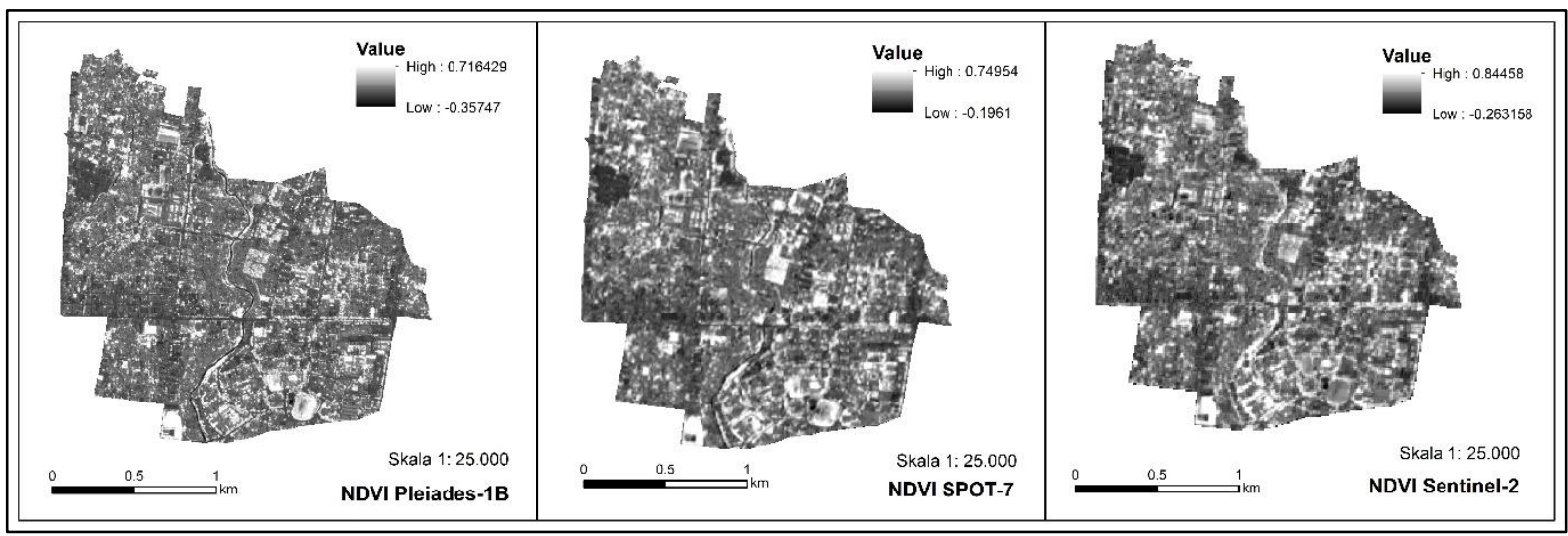

Gambar 2. Normalized Difference Vegetation Index (NDVI) pada masing-masing citra

\section{Tekstur Grey Level Co-occurrence Matrix}

Tesktur dapat diartikan sebagai informasi kekasaran suatu kenampakan objek pada citra yang tersusun oleh variasi derajat keabuan (rona) piksel-piksel citra. Danoedoro (2012) mendefinisikan tekstur sebagai frekuensi perubahan rona pada tingkat resolusi terkecil yang dapat diamati secara visual pada citra. Arnia dan
Munadi (2018) mengartikan tekstur sebagai suatu susunan yang terdiri dari elemen dasar yang berulang dan terjadi pada posisi, deformasi, dan orientasi yang berbeda pada suatu luasan yang ditentukan. Salah satu teknik perolehan informasi tesktur adalah dengan fitur Grey Level Cooccurrence Matrix (GLCM). Perhatikan Gambar 3 berikut ini.

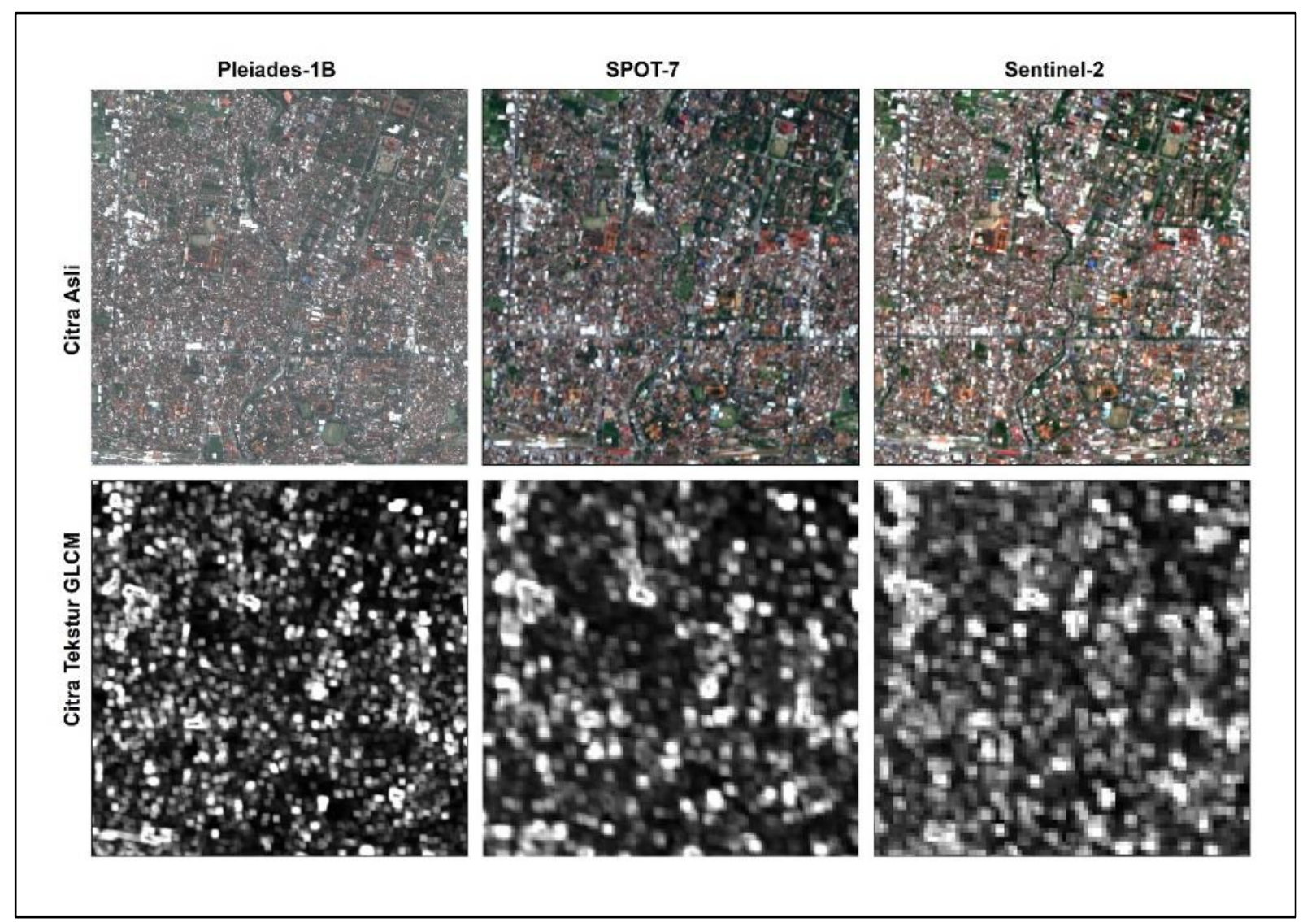

Gambar 3. Tekstur GLCM variance pada masing-masing citra 
Leonita (2018) dan Duque et al (2017) menggunakan tesktur GLCM sebagai salah satu parameter untuk mendeteksi permukiman kumuh. Fitur GLCM terdiri dari beberapa macam informasi tekstur Penelitian ini menggunakan salah satu fitur informasi yaitu variance. Variance merupakan salah satu rumus statistik yang menunjukkan tingkat keragaman suatu populasi, dalam hal ini variance merepresentasikan tingkat keragaman sekumpulan nilai piksel. Kuffer et al (2016b) menggunakan fitur variance sebagai salah satu parameter untuk mendeteksi permukiman kumuh. Fitur variance menampakkan tekstur objek yang beragam tergantung dari nilai-nilai pikselnya. Pada sekumpulan piksel dengan nilai variance yang rendah cenderung menunjukkan perbedaan selisih antar nilai piksel yang rendah pula. Hal tersebut menunjukkan objek dalam sekumpulan piksel berjenis dan berukuran relatif lama.
Sebaliknya, nilai variance yang tinggi cenderung menunjukkan perbedaan selisih nilai antar piksel yang signifikan. Jika dilihat dari kenampakan citranya, nilai variance tinggi merupakan kenampakkan objek yang relatif beragam baik dari segi ukuran, bentuk, dan warnanya. Hal tersebut menunjukkan heterogenitas yang tinggi pada area tersebut.

Penelitian ini menggunakan beberapa ukuran window GLCM untuk masing masing citra digunakan. Setiap ukuran window menghasilkan output piksel dan variasi tekstur yang berbeda. Tujuan peenggunaan ukuran window yang berbeda adalah untuk menemukan kombinasi yang sesuai dengan resolusi spasial citra dan tingkat akurasi klasifikasi permukiman kumuh yang paling tinggi. Gambar 4 menunjukkan diagram alir penelitian ini.

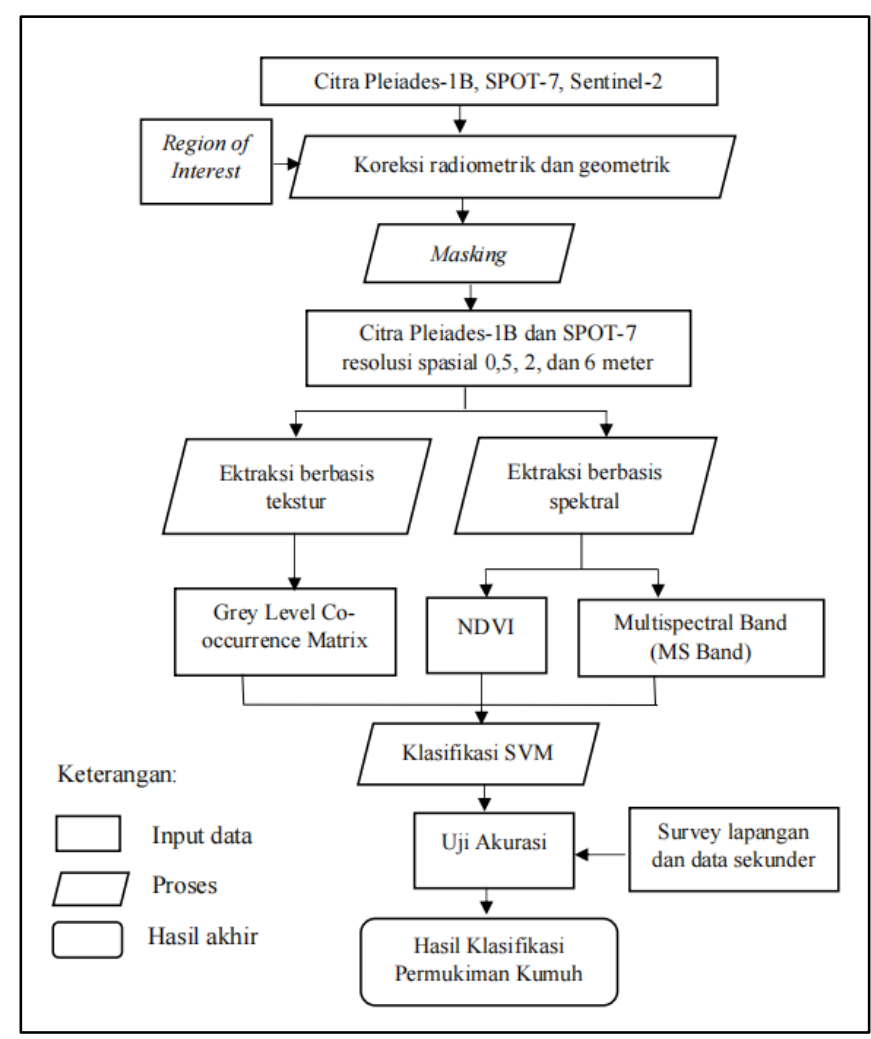

Gambar 4. Diagram Alir Penelitian

\section{Klasifikasi Support Vector Machine (SVM}

Support Vector Machine (SVM) adalah klasifikasi berbasis machine learning yang melakukan klasifikasi secara terbimbing berdasarkan training area tiap kelas yang ditentukan. SVM merupakan teknik pembelajaran statistik non-parameterik terbimbing yang tidak 
menggunakan asumsi pada distribusi datanya. Konsep SVM adalah klasifikasi dengan cara memisahkan antara dua kelas atau lebih dengan mengidentifikasi hyperplane atau batas pemisah antar kelas. Hyperplane merupakan batas keputusan (decision boundary) yang meminimalkan kesalahan klasifikasi pada proses penentuan training area (Mountrakis et. al., 2011).

Proses klasifikasi menggunakan data sampel area atau training area beberapa kelas. Objek area yang dikelaskan antara lain permukiman kumuh, non-kumuh, lahan terbangun non-permukiman, dan area bervegetasi. Training area yang digunakan sebanyak 40 sampel, masing-masing objek diberi 10 sampel. Area sampel berbentuk kotak/grid yang ukurannya dihitung menggunakan rumus dari Justice dan Townshend (McCoy, 2005) sebagai berikut:

$$
A=P(1+2 L)
$$

dimana: $A=$ Luas sampel, $P=$ Ukuran piksel, $L=$ Akurasi lokasi dalam piksel (misal 0,5 piksel). Akurasi lokasi ditentukan sebesar 1 meter. Berdasarkan rumus di atas, maka luas area sampel adalah 6 meter (Pleiades-1B), 18 meter (SPOT-7), dan 20 meter (Sentinel-2).

\section{Hasil dan Pembahasan}

Proses klasifikasi menghasikan 6 layer pada dua daerah penelitian (Gambar 5 dan Gambar 6). Kedua daerah penelitian ini memiliki karakteristik lingkungan permukiman yang berbeda. Nampak pada Gambar 5, menunjukkan perbedaan karakteristik permukiman kumuh hasil survei pada kedua daerah penelitian dilihat dari citra Pleiades1B. Daerah penelitian 1 merupakan area yang terdiri atas 5 kelurahan, yaitu: Kelurahan Terban, Cokrodiningratan, Kotabaru, Gowongan, dan Karangwaru.

Karakteristik permukiman daerah penelitian 1 merupakan permukiman sangat padat penduduk dan sebagian besar berada di bantaran Sungai Code dan Sungai Buntung. Pola permukiman cenderung tidak teratur dan mengikuti morfologi sempadan sungai. Sebagian permukiman seperti di Kelurahan Kotabaru memiliki pola yang teratur dan tertata rapi.

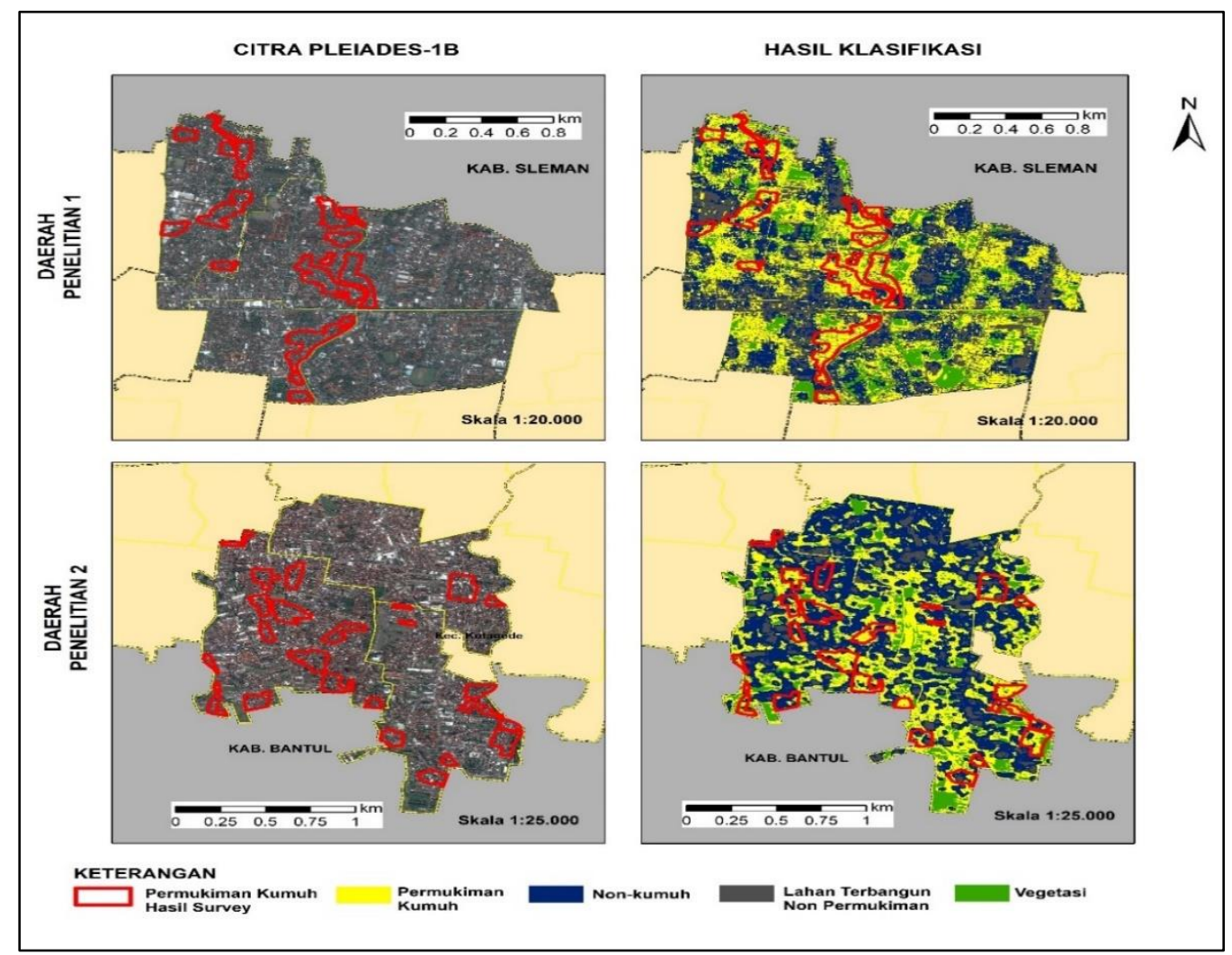

Gambar 5. Hasil klasifikasi layer Pleiades-1B GLCM 3×3 
Daerah penelitian 2 terdiri atas Kelurahan Pandeyan, Sorosutan, dan Giwangan. Permukiman di wilayah ini tersebar merata dan cenderung tidak mengikuti morfologi sempadan sungai. Sebagian permukiman memiliki kepadatan yang tinggi. Terdapat pula area permukiman dengan tingkat kepadatan sedang. Sebagian area di Kelurahan Giwangan dan Sorosutan masih terdapat lahan terbuka dan pertanian. Selain kawasan permukiman, terdapat pula kawasan industri dan perniagaan. Perbedaan karakteristik lingkungan permukiman tersebut berpengaruh terhadap hasil klasifikasi permukiman kumuh. Gambar 5, menunjukkan contoh hasil klasifikasi dari layer Sentinel-2 GLCM 3×3. Nampak pada daerah penelitian 1 , layer lebih banyak mengklasifikasi area permukiman kumuh (warna kuning), sedangkan pada layer daerah penelitian 2 lebih banyak mengklasifikasi permukiman tidak kumuh (warna biru gelap). Secara keseluruhan, hasil menunjukkan klasifikasi berlebih (over classification) pada kelas permukiman kumuh. Hal ini disebabkan oleh penggunakaan citra resolusi spasial sangat tinggi yang dapat mengklasifikasi secara detail objek yang dikelaskan. Kesamaan warna atap antara permukiman kumuh dan tidak kumuh menyebabkan hasil klasifikasi saling tumbang tindih dan kurang konsisten.

Uji akurasi dilakukan untuk mengetahui tingkat akurasi hasil klasifikasi dari masing-masing layer. Metode uji akurasi yang digunakan adalah confusion matrix (matriks kesalahan). Sampel uji akurasi berjumlah 30 sampel untuk tiap daerah penelitian, yang terdiri atas 12 sampel kumuh, 8 sampel non-kumuh, 6 sampel lahan terbangun non-permukiman, dan 4 sampel vegetasi. Data sampel validasi merupakan data primer hasil observasi lapangan dan data sekunder peta permukiman kumuh Kota Yogyakarta tahun 2018. Pemilihan lokasi sampel dilakukan dengan metode stratified random sampling menggunakan fungsi random points pada aplikasi ArcMap. Hasil uji akurasi dapat dilihat pada Tabel 1.

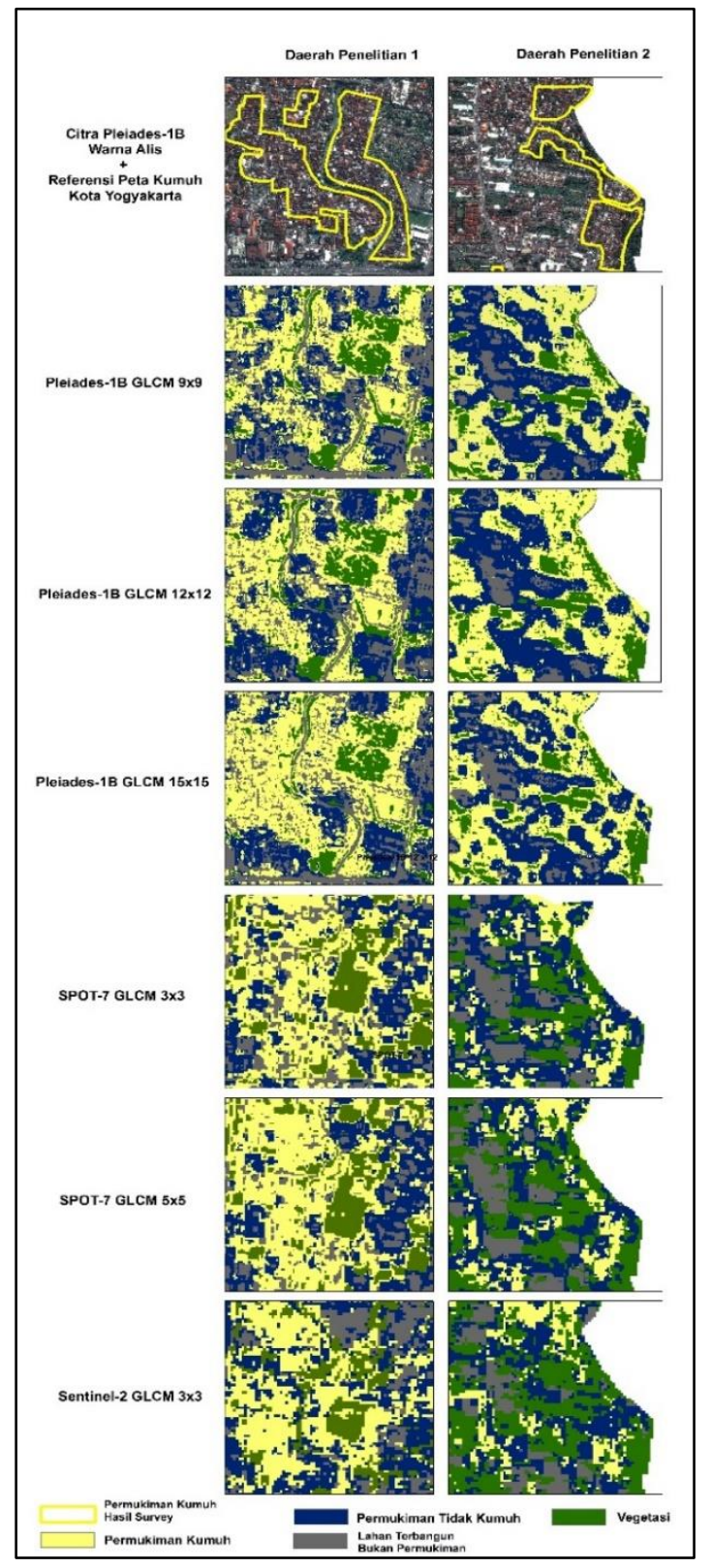

Gambar 6. Hasil klasifikasi seluruh layer pada area terpilih

Tabel 1. Hasil Uji Akurasi

\begin{tabular}{|c|c|c|}
\hline \multirow[t]{2}{*}{ Layer Hasil Klasifikasi } & \multicolumn{2}{|c|}{$\begin{array}{c}\text { Tingkat Akuras } \\
\text { Keseluruhan }\end{array}$} \\
\hline & $\begin{array}{c}\text { Daerah } \\
1\end{array}$ & $\begin{array}{c}\text { Daerah } \\
2\end{array}$ \\
\hline Pleiades 1B GLCM 9x9 & $51,87 \%$ & $66,17 \%$ \\
\hline Pleiades 1B GLCM 12×12 & $49,49 \%$ & $55,91 \%$ \\
\hline Pleiades 1B GLCM 15x15 & $51,64 \%$ & $65,93 \%$ \\
\hline SPOT-7 GLCM 3×3 & $43,46 \%$ & $60,02 \%$ \\
\hline SPOT-7 GLCM 5×5 & $49,01 \%$ & $54.51 \%$ \\
\hline Sentinel-2 3×3 & $56,25 \%$ & $55,51 \%$ \\
\hline
\end{tabular}

Sumber: Analisis Data, 2021 
Berdasarkan Tabel 1, diketahui bahwa nilai akurasi tertinggi dihasilkan oleh layer Sentinel-2 GLCM 3x3 pada daerah penelitian 1 dengan nilai akurasi sebesar 56,25 \%, sedangkan nilai akurasi tertinggi pada layer daerah penelitian 2 diperoleh dari layer Pleiades-1B GLCM 9x9 sebesar 66,17\%. Akurasi terendah dihasilkan oleh layer SPOT-7 GLCM 3x3 di daerah penelitian 1 dan Sentinel-1 GLCM 3x3, masing-masing sebesar 43,46\% dan 54,51\%. Hasil akurasi pada daerah penelitian 1 dan 2 tidak menunjukkan konsitensi antara besarnya resolusi spasial citra dan ukuran window GLCM.

Nilai tersebut merupakan nilai akurasi keseluruhan dari semua kelas yang terklasifikasi benar di lapangan (permukiman kumuh, nonkumuh, lahan terbangun, dan vegetasi). Artinya, nilai tersebut tidak menggambarkan nilai akurasi untuk tiap kelas. Untuk melihat tingkat akurasi khususnya pada kelas permukiman kumuh, maka perlu melihat akurasi produser (producer accuracy) dan pengguna (user accuracy) pada kelas permukiman kumuh. Akurasi produksi merupakan nilai akurasi yang didasarkan pada jumlah yang terklasifikasi benar di lapangan sesuai dengan peta acuan (reference map). Sebaliknya, akurasi pengguna adalah nilai akurasi yang didasarkan pada jumlah kelas terklasifikasi benar pada peta acuan sesuai dengan kondisi nyata di lapangan. Nilai akurasi produser tertinggi dihasilkan oleh layer SPOT-7 GLCM 5×5 sebesar $68,87 \%$ pada daerah penelitian 1 dan layer SPOT7 GLCM $3 \times 3$ sebesar 44,83\% pada daerah penelitian 2. Akurasi pengguna tertinggi dihasilkan oleh layer Sentinel-2 GLCM 3X3 dan Pleiades-1B GLCM 9x9 masing-masing sebesar $61,86 \%$ dan $57,71 \%$. Besarnya nilai akurasi pada akurasi produser dan pengguna menunjukkan konsistensi pemilihan sampel untuk pemodelan (klasifikasi) dan sampel uji. Semakin rendah selisih nilai antara nilai akurasi produser dengan pengguna, semakin baik pemilihan lokasi sampelnya. Hal ini karena hasil klasifikasi yang dihasilkan dari data referensi dan lapangan relatif sama. Perhatikan Tabel 2 berikut ini.

Tabel 2. Akurasi produksi dan pengguna pada kelas permukiman kumuh

\begin{tabular}{lrrrr}
\hline \multirow{2}{*}{ Layer } & \multicolumn{2}{c}{ Daerah penelitian 1 } & \multicolumn{2}{c}{ Daerah penelitian 2 } \\
\cline { 2 - 5 } & $\begin{array}{c}\text { Producer } \\
\text { accuracy }\end{array}$ & $\begin{array}{c}\text { User } \\
\text { accuracy }\end{array}$ & $\begin{array}{c}\text { Producer } \\
\text { accuracy }\end{array}$ & $\begin{array}{c}\text { User } \\
\text { accuracy }\end{array}$ \\
\hline Pleiades-1B GLCM 9X9 & 44.87 & 55.92 & 39,38 & $\mathbf{5 7 , 7 1}$ \\
\hline Pleiades-1B GLCM 12X12 & 46.43 & 55.45 & 43.84 & 42.8 \\
\hline Pleiades-1B GLCM 15X15 & 59.04 & 53.29 & 44,52 & 53,93 \\
\hline SPOT-7 GLCM 3X3 & 64.20 & 49.70 & $\mathbf{4 4 , 8 3}$ & 56,88 \\
\hline SPOT-7 GLCM 5X5 & $\mathbf{6 8 . 8 7}$ & 50.43 & 30,42 & 50,98 \\
\hline Sentinel-2 GLCM 3X3 & 61.22 & $\mathbf{6 1 . 8 6}$ & 35,57 & 47,92 \\
\hline
\end{tabular}

Sumber: Hasil Analisis Data, 2021

Berdasarkan Tabel 2, layer yang memiliki selisih akurasi terkecil adalah Sentinel-2 GLCM $3 \times 3$. Nilai akurasi produser pada layer tersebut sebesar $61,22 \%$ dan akurasi pengguna sebesar $61,68 \%$. Terdapat selisih $0,64 \%$ pada kedua akurasi. Artinya, jika terdapat kelas permukiman kumuh pada layer, maka kemungkinan benar di lapangan adalah $61,22 \%$. Jika terdapat area permukiman kumuh di lapangan, maka persentase terklasifikasi sebagai permukiman kumuh pada layer sebesar $61,68 \%$. Hasil akurasi ini lebih rendah dari penelitian sejenis sebelumnya yang mencapai tingkat akurasi keseluruhan di atas $80 \%$. Penelitian Leonita (2018) yang dilakukan di Kota Bandung menghasilkan akurasi tertinggi sebesar $88,5 \%$. Sementara, penelitian Kuffer et al (2016b) di Kota Mumbai dan Ahmedabad, India memperoleh akurasi sebesar $87 \%$ dan $88 \%$. Penelitianpenelitian tersebut menggunakan lebih banyak fitur parameter dari citra, meliputi: spektral, 
tekstur, morfologi, dan struktur, yang memerlukan percobaan komputasi dan waktu lebih lama. Dibanding penelitian sejenis, penelitian ini menggunakan parameter dan percobaan komputasi yang relatif sederhana sehingga mempercepat proses klasifikasi.

Secara kesuluruhan, nilai akurasi yang dihasilkan oleh semua layer masih tergolong rendah untuk klasifikasi penggunaan lahan, terutama untuk kelas permukiman kumuh. Hal ini dikarenakan proses klasifikasi hanya menggunakan informasi spektral dan tekstur yang berasal dari respon permukaan atap permukiman. Klasifikasi hanya didasarkan pada kenampakan dari atas. Berbeda dengan pemetaan permukiman kumuh berbasis survei yang secara detail dapat menilai kondisi lingkunganya. Namun demikian, metode ini dapat dikembangkan dengan metode dan parameter lain sehingga dapat meningkatkan nilai akurasi dan proses lebih cepat.

\section{Simpulan}

Pemetaan permukiman kumuh berbasis informasi spektral dan tekstur dapat dilakukan sebagai metode alternatif untuk deteksi awal sebelum dilakukan survei. Namun demikian, diperlukan penelitian lebih lanjut dengan pengembangan parameter dan metode klasifikasi. Berdasarkan hasil penelitian ini dan penelitian sebelumnya, metode dan parameter yang digunakan masih bersifat lokal yang disesuaikan dengan karakter wilayah permukiman kumuh yang diteliti. Diharapkan dengan pengembangan metode deteksi dapat meningkat akurasi hasil klasifikasi dan pemetaan permukiman kumuh, serta dapat diaplikasikan ke banyak wilayah permukiman.

\section{Ucapan terima kasih}

Penulis menyampaikan terimakasih kepada Sigit Setiawan, ketua bidang permukiman Dinas Pekerjaan Umum Permukiman dan Perumahan Rakyat Kota Yogyakarta, Camat, Lurah, dan Ketua RW yang telah memberikan izin pengambilan data lapangan.

\section{Referensi}

Arnia, F. dan Munadi, K. (2018). Pengantar Teknik Pengolahan Citra dan Visi Komputer. Yogyakarta: Penerbit Ombak.

Baghdadi, N., dan Zribi, M. (2016). Land Surface Remote Sensing in Urban and Coastal Areas. London: ISTE Press.

Brown, Jesslyn. (2018). NDVI the Foundation for Remote Sensing Phenology. https://www.usgs.gov/core-sciencesystems/eros/phenology/science/ndvifoundation-remote-sensing-phenology.

Danoedoro, P. (2012). Pengantar Penginderaan Jauh Digital. Yogyakarta: Penerbit Andi.

Duque, J.C., Patino, J.E. dan Betancourt, A. (2017). Exploring the potential of machine learning for automatic slum identification from VHR imagery. Remote Sensing, 2017(9), 1-23. doi 10.3390/rs9090895.

Huang, S., Tang, L. Hupy, J.P., Wang, Y., Shao, G. (2021). A Commentary Review on The Use of Normalized Difference Vegetation Index (NDVI) in The Era of Popular Remote Sensing. Journal of Forestry Research. 2021(1), 1-6. https://doi.org/10.1007/s11676-020-01155-

1.

Kohli, D., Sliuzas, R., Kerle, N., dan Stein, A. (2012) An Ontology of Slums for Image-based Classification. Computers, Environment, and Urban Systems. 2012(12), 154-163. doi:10.1016/j.compenvurbsys.2011.11.001.

Kuffer, M., Pfeffer, K., dan Sliuzas, R. (2016). Slum from Space-15 Years of Slum Mapping Using Remote Sensing, Remote Sensing, 2016(8), 129.

Kuffer, M., Pfeffer, K., Sliuzas, R., dan Baud, I. (2016b). Extraction of Slum Areas From VHR Imagery Using GLCM Variance. IEEE Journal of Selected Topic in Applied Earth Observation and Remote sensing, 2016(9), 1830-1830. doi:10.1109/JSTARS.2016.2538563.

Kupidura, P. (2019). The Comparison of Different Methods of Texture Analysis for Their Efficacy for Land Use Classification in Satellite 
Imagery. MDPI Remote Sensing, 2019(11), 1233, doi:10.3390/rs11101233.

Leonita, G, Kuffer, M., Sliuzas, R., dan Persello, C. (2018). Machine learning-Base Slum Mapping, in Support Slum Upgrading Program: Case Study in Bandung. Remote Sensing, 2018(10), 1-26. doi:10.3390/rs10101522.

Mboga, N., Persello, C., Bergado, J.R., dan Stein A. (2008). Detection of Informal Settlement from VHR Images Using Convulutional Neural Networks. Remote Sensing, 2017(9), 1-18. doi10:1109/ACCESS.2018.2812999.

McCoy, R.M. (2005). Field Methode in Remote Sensing. The Guilford Press: New York.

Mountrakis, G., Im, J., dan Ogole, C. (2011). Support Vector Machine in Remote Sensing: A Review. ISPRS Journal of Photogrammetry and Remote Sensing. 2011(66). 247-259. doi:10.1016/j.isprsjprs.2010.11.001.

Muta'ali, L dan Nugroho, A.R. (2016). Perkembangan Program Penanganan
Permukiman Kumuh di Indonesia dari Masa ke Masa. Yogyakarta: UGM Press.

Richards, J.A., dan Jia, X. (2005). Remote Sensing Digital Image Analysis $4^{\text {th }}$ Edition. Berlin: Springer.

Somvanshi, S.S., dan Kumari, M. (2020). Comparative Analysis of Different Vegetation Indices with Respect to Atmospheric Particulate Pollution using Sentinel Data. Applied Computing and Geosciences, 2020(7). https://doi.org/10.1016/j.acags.2020.100032. Sori, N.D. (2012) Identifying and Classifying Slum Development Stage from Spatial Data. Tesis. University of Twente The Netherlands.

Undang-undang Nomor 01 Tahun 2011 tentang Perumahan dan Kawasan Permukiman.

Xue, J. dan Su B. (2017) Significant Remote Sensing Vegetation Indices: A Review of Development and Applications. Hindawi Journal of Sensor. 201, 1 17. https://doi.org/10.1155/2017/1353691 